\title{
Miranda
}

Revue pluridisciplinaire du monde anglophone /

Multidisciplinary peer-reviewed journal on the English-

speaking world

$21 \mid 2020$

Modernism and the Obscene

\section{Linda S. Ferber, Nancy K. Anderson (eds.), The American Pre-Raphaelites - Radical Realists}

\section{Muriel Adrien}

\section{OpenEdition}

Journals

Édition électronique

URL : http://journals.openedition.org/miranda/30103

DOI : 10.4000/miranda.30103

ISSN : 2108-6559

Éditeur

Université Toulouse - Jean Jaurès

\section{Référence électronique}

Muriel Adrien, « Linda S. Ferber, Nancy K. Anderson (eds.), The American Pre-Raphaelites - Radical Realists », Miranda [En ligne], 21 | 2020, mis en ligne le 13 octobre 2020, consulté le 16 février 2021. URL : http://journals.openedition.org/miranda/30103 ; DOI : https://doi.org/10.4000/miranda.30103

Ce document a été généré automatiquement le 16 février 2021.

\section{cc) (i) () $\Theta$}

Miranda is licensed under a Creative Commons Attribution-NonCommercial-NoDerivatives 4.0 International License. 


\title{
Linda S. Ferber, Nancy K. Anderson (eds.), The American Pre-Raphaelites - Radical Realists
}

\author{
Muriel Adrien
}

\section{RÉFÉRENCE}

Linda S. Ferber, Nancy K. Anderson (eds.), The American Pre-Raphaelites - Radical Realists (Washington, National Gallery of Art, 2019), 294 p, ISBN 978-0-300-24252-2

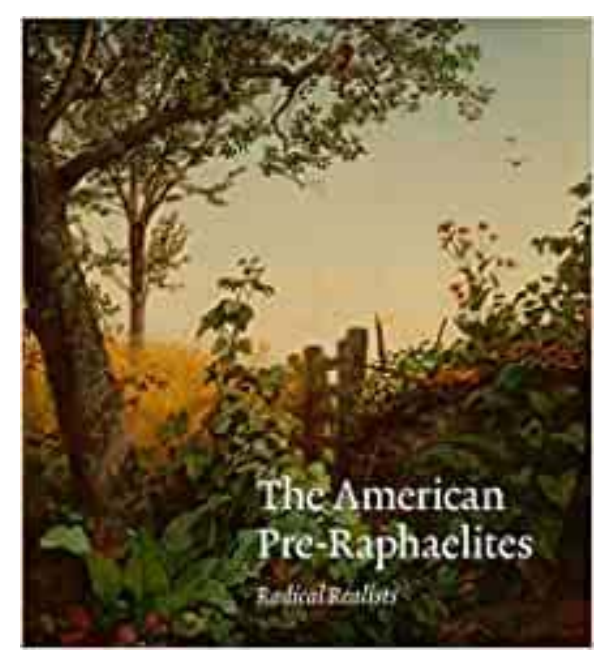

1 The American Pre-Raphaelites - Radical Realists is the catalog of an exhibition of some 90 works by American artists influenced by John Ruskin (1819-1900) in celebration of the 200th anniversary of his birth, held at the National Gallery of Art in Washington DC from April 14 to July 21, 2019. The exhibit took place 34 years after a pioneering exhibition organized by the Brooklyn Museum in 1985, The New Path: Ruskin and the American Pre-Raphaelites, named after their short-lived radical mouthpiece and journal. 
The catalog is a collection of chapters edited by the curators of the exhibit, Linda S. Ferber (museum director emerita and senior art historian at the New York Historical Society) and Nancy K. Anderson (curator and head of the department of American and British paintings at the National Gallery of Art), complete with illustrations, a plates checklist, portraits and short biographies of the artists, a selected bibliography and an index.

2 Linda Ferber starts by introducing the group of artists who were dubbed the American Pre-Raphaelites for their Ruskinian allegiance. Ruskin never travelled to the United States but his reformist ideas rejecting academic art and his appeal for artworks that focused on the exacting details of the natural world found a resounding echo in the United States, especially among ardent followers such as Fidelia Bridges, Charles Herbert Moore, Henry Roderick Newman, William Trost Richards, the Hills, Robert J. Patkinson, and most notably Thomas Charles Farrer, a veteran of the Union army. This British-born artist who studied with Ruskin and Rossetti spearheaded the creation of the Association for the Advancement of Truth in Art in 1863.

Ruskin's call for meticulous descriptions of nature was, according to Asher B. Durand, decisive in the emergence of a national school. Under the influence of the best-selling Elements of Drawing (1857), American Pre-Raphaelites painted out of doors directly from nature, and did so with intense attention to detail. Like the British Pre-Raphaelites, they were highly critical of the old system, theirs being the Hudson River School or paintings such as Leutze's in the exhibition for the Great Metropolitan Fair in 1864. essay also focuses on the architect members Peter Bonnett Wight and Russell Sturgis Jr. who conducted projects in the Gothic revival style advocated by Ruskin.

The heyday of the movement was in the mid-1860s, during the Civil War years: their reformist agenda included the preservation of the Union and the abolition of slavery, as encoded in the political subtext of their pictures. Although they were quite aware of their own historical importance, the group disbanded by 1870 and they went their separate ways. The group was a catalyst for the founding of the American Watercolor Society and a harbinger of the American Aesthetic movement.

Tim Barringer's chapter gives an overview of the British Pre-Raphaelite Brotherhood and of the influential role of Ruskin's teachings, before listing the instances during which Ruskin was in contact with Americans. Ruskin met W.J. Stillman who cofounded The Crayon with John Durand, son of Asher Brown Durand. His closest friend was Charles Eliot Norton, who would become the first professor of History of Art at Harvard University. Charles Herbert Moore, one of the American Pre-Raphaelites, was Ruskin's travelling companion in 1876-78, and copied Italian works for him and Norton. As for T.C. Farrer, he exported the zeal for reform of the Working Men's college to the US when he emigrated in 1858.

6 Sophie Lynford's chapter focuses on the political subtext of the works of the American Pre-Raphaelites. Even though no images of the movement illustrated slavery specifically, their artwork endeavored to advance political causes. The Association for the Advancement of the Truth in Art had internalized Ruskin's idea that art was linked to the moral condition of a country. British-born T.C. Farrer's engagement with progressive Christian socialism originated at the Working Men's College, where Chartism sparked fervent political debate. Chartism shared a common purpose with African American abolitionism for which there was an active lecture circuit in England in the 1840 s and 1850s. In the United States, Farrer enlisted in the Union army for three 
months. He also stayed with his wife in the house of Gabriel Joseph B. Parsons who had taken part in many significant battles fought by the Army of the Potomac. Farrer was the only American Pre-Raphaelite to produce a significant body of narrative work, such as Gone Gone (1860), which was steeped in a sense of foreboding with the impending war. Lynford connects the painting with Millais's treatment of the same theme in various pictures, such as The Black Brunswicker.

7 The architects Peter Bonnett Wight and Russell Sturgis Jr. strongly adhered to Ruskinian ideas, carrying them to unprecedented heights. Not only did they promote Gothic revivalism so as to counter the pernicious effects of mechanization on the arts; they also found in that architecture the means to promote the values of egalitarianism, manual labor and craftsmanship, the importance of sourcing materials locally, as well as the display of native flora and fauna in ornaments and decoration. Lynford describes the boldness of buildings by Wight, such as the National Academy of Design, or the North's first army field hospital.

8 The Association repudiated Thomas Cole, Asher Durand, Frederick Church, Albert Bierstadt as these artists were believed to have condoned an expansionist ethos in their landscape paintings, extolling or at least tacitly endorsing the policy of the Manifest Destiny. Indeed, in their idealized compositions of the American sublime, the viewer could take cognitive possession of the scene and by extension of the physical landscape. The American Pre-Raphaelites spurned formulaic entry points and picturesque markers (such as repoussoirs, winding paths...) and substituted these exhausted tropes with arduous hyper-realistic mimesis, more consonant with their quest for truth. Lynford gives a few examples of the faithful landscape transcriptions that were favored over idealized landscapes. Moore's Hudson River, Above Catskill (1865) modestly features a small strip of the Hudson riverfront, a rocky bank with an unusual assemblage of unseemly detritus. It foregrounds the trope of the wrecked or stranded boat-emblematic of a marooned situation. The quasi-taxonomic profusion of botanical and geological residue actually exceeds the realist mandate set by Ruskin. Likewise, John Henry Mills's literal Study of Trap Rock features a broken jumble of cleaved and angled blocks as an allegory of wartime carnage. The claim behind these non-showy, discrete subjects, was that no object was less deserving of the painters' care; this acuity of vision was meant to convey values of equality. Unlike the View from Mount Holyoke, Northampton, Massachusetts, after a Thunderstorm-The Oxbow (1836) by Thomas Cole, the same Catskill landscape by Farrer in View of Northampton from the Dome of the Hospital (1865) is treated as still life. The piece is a collection of disparate objects rather than a grand and unified Claudian vision. Moreover, Farrer takes the opposite vantage point to Cole - from the State Hospital for the Insane-many of whose inhabitants were former Union soldiers- as this was more consonant with his purpose.

Barbara Dayer Gallati starts by saying that the elaborate and virtuoso literalism of the American Pre-Raphaelites and their depiction of nature's minutiae did not preclude them from engaging with thematic content. She goes over the privileged themes that arise in Pre-Raphaelite productions. The first theme is that of portraits of artists intensely absorbed by their work, which seems consistent with the Pre-Raphaelites' embrace of the virtues of industrious labor. That occupation is sometimes musicmaking as it requires practice and dedication. Another leitmotiv is the floral symbolism, common in Victorian culture. Of course, the American artists preferably turned to North American species, often humble unassuming wildflowers. The Biblical 
or Shakespearian symbol of the neglected unweeded garden, albeit showing fine botanical detail, is also frequent and draws on Holman Hunt's Light of the World. Some paintings revel in hidden symbolism and Dayer Gallati compares Hunt's Awakening Conscience with Farrer's Practicing Lesson, as well as the latter's self-portrait with Van Eyck's Arnolfini Portrait. Embedded paintings in scenes of separation and loss successfully make a self-reflexive comment on the medium of the picture itself, as can be seen in Gone! Gone!. The reference of Millais' Huguenot Lover equates the separation of two lovers to that of a country torn apart during the Civil War.

Mark Mitchell argues that Ruskin's influence on the minor genre of still life was particularly significant in the United States. His writings were read loosely as validation for the primacy of visual perception over artistic convention, and their focus on the intimate appreciation of nature and the democratic quality of an egalitarian view of things was resonant with the young American republic. The most famous work of art by Ruskin in the United States, Fragment of the Alps (c.1854-56), a watercolor belonging to Charles Eliot Norton, his longtime friend and a champion of the American movement, toured the United States in 1857-58. It embodied Ruskin's exhortation that artists observe nature closely and transcribe it faithfully. Mitchell compares and contrasts it with Charles Herbert Moore's Rocks by the Water. He also compares John William Hill's Bird's Nest and Dog Roses (1867) with Hunt's Bird's Nest with Sprays of Apple Blossoms (c. 1847). Most still lives were actually foregrounded in their natural setting, more than on tabletops.

11 American Pre-Raphaelites also drew inspiration from the German Biedermeier that accompanied a wave of German immigration. This accessible style of painting appealed to the burgeoning American middle classes, and artists such as Severin Rosen were popular among American art collectors. American Pre-Raphaelites infused their still lives with the lush sensuality and intense colorism of vibrant flowers and lustrous fruit found in the Biedermeier style, even though Ruskin would have them turn to more austere and mundane subjects. Some, such as Fidelia Bridges, advanced nature studies towards the dawning Aesthetic movement.

Diane Waggoner explores the links between the works of the Pre-Raphaelites and photography. Ruskin's emphasis on the close scrutiny of nature, on rendering minute, sharp and legible details, was both a concern of Pre-Raphaelite practice and a feature of photography, technically and thematically. As mimetic realism was characteristic of photography, the medium contributed to the rise of realism as an aesthetic mode. Its specific modalities (flattened forms, cropped visual field) were also to be found in paintings. Waggoner first focuses on WJ Stillman, a forbear of American PreRaphaelites who travelled to London a few times. Stillman befriended Lowell and Norton and, via them, Ralph Waldo Emerson and Louis Agassiz. They all embarked on a camping expedition in 1858 in the Adirondacks with Stillman as a guide. Stillman engaged in photo-making whenever he came back to the Adirondacks and lauded photography in the Crayon (precursor to the New Path). Though none of the artists of the Association are known to have practiced photography themselves, their paintings were reproduced as photos. The New Path pushed for images that were legible to the botanist and geologist. Photographers such as John Moran went for subjects akin to those singled out by American Pre-Raphaelites, taking pictures of the tangled and profuse underbrush of the forest. However, photography's exactitude was probably one of the factors that accelerated the demise of the Pre-Raphaelites. 
13 Janice Simon analyzes the content of the austere-looking New Path (no images, no advertisements) which lasted only 12 months, and which was edited successively by Clarence Cook, and Sturgis as of May 1864. She compares it with its precedents and models, The Germ (1850) and The Crayon (1855-61). The Pre-Raphaelites insisted unwaveringly on the observation of Nature, for they believed divinely ordained beauty was attained through direct study of nature-what they called "the truth of nature"which they extolled as the foundation of what was moral. They were intent on marking an iconoclast and radical departure from the US's previous servile imitation of European models, railing against the inauthentic and elaborate spectacle displays of the huge canvases of the Hudson River School. They added that America had a comparative edge over the United Kingdom as it was unencumbered by outmoded and entrenched traditions and prejudices. As ardent supporters of the Union cause, this independence of tone was also political. The freedom allotted to slaves was also that of their artistic endeavors, they claimed. Their ideas in the journal were indebted to the Emersonian vision: they harnessed its spirit of self-reliance, and the idea of an active soul engaged freely with the world. Simon also spots a few literary influences such as Tennyson and examines how exhibition reviews evaluated artists, mainly according to their faithfulness to nature.

14 All in all, it is paradoxically through the ubiquitous influence of a British-born critic, Ruskin, that the Pre-Raphaelites hoped to launch a distinctive American school. The fact that they are dubbed American Pre-Raphaelites is due to the influence of Ruskin's writings and an extension of his vision more than to any real connection with the real British Pre-Raphaelites, apart from Farrer with Rossetti. Their preference for landscape and still life over medieval inspiration reflected the fact that medievalism was not really central to American concerns whereas the theme of the land was more consistent with their identity-building.

Even if one may regret repetitions between chapters and the fact that plates and texts are often not on the same page (not always making for easy and smooth reading), this beautiful catalog certainly provides informative and enlightening scholarship on this little-known short-lived movement, with large high quality reproductions of paintings-many of which had never been publicly exhibited until then. The exhibition "Pre-Raphaelites Vision" held at the Tate in 2004 was the first survey to include American Pre-Raphaelites, Henry Roderick Newman and expatriate Thomas Charles Farrer. This exhibit showcases their work and updates research on the movement in a much more comprehensive way. However, pieces of the puzzle are still missing. Some of Farrer's narrative paintings remain unlocated, such as Evening Thoughts or April, 1861, and it would be all the more interesting to find them as the American Pre-Raphaelites generally had an aversion to overt narratives. This catalog will certainly foment scholars' eagerness to find paintings yet to be discovered, which may portend further discoveries on the American Pre-Raphaelites. 
INDEX

Mots-clés : Préraphaélites, école de l'Hudson, Biedermeier, peinture américaine, nature morte, photographie, Guerre de Sécession

Keywords : Pre-Raphaelites, Association for the Advancement of Truth in Art, Hudson River School, American Aesthetic movement, Great Metropolitan Fair, National Academy of Design, Manifest Destiny, Catskill, Adirondacks, Biedermeier, still life, American painting, photography, Civil war

\section{AUTEURS}

\section{MURIEL ADRIEN}

Maître de Conférences

Université de Toulouse 2-Jean Jaurès

muriel.adrien@univ-tlse2.fr 